\title{
Data report: clay mineral assemblages in cuttings from Hole C0002F, IODP Expedition 338, upper Nankai Trough accretionary prism'
}

Michael B. Underwood ${ }^{2}$ and Chen Song ${ }^{3}$

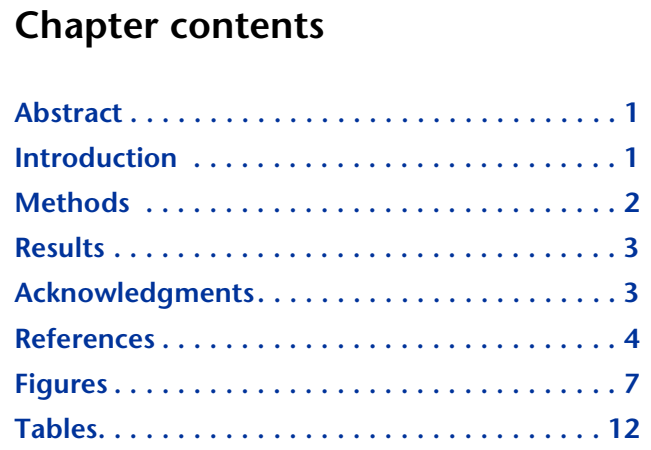

'Underwood, M.B., and Song, C., 2016. Data report: clay mineral assemblages in cuttings from Hole C0002F, IODP Expedition 338, upper Nankai Trough accretionary prism. In Strasser, M., Dugan, B., Kanagawa, K., Moore, G.F., Toczko, S., Maeda, L., and the Expedition 338 Scientists, Proceedings of the Integrated Ocean Drilling Program, 338: Yokohama (Integrated Ocean Drilling Program). doi:10.2204/iodp.proc.338.206.2016

${ }^{2}$ Department of Earth and Environmental Science, New Mexico Institute of Mining and Technology, 801 Leroy Place, Socorro New Mexico 87801, USA UnderwoodM@missouri.edu

${ }^{3}$ Department of Geological Sciences, University of Missouri, 101 Geology Building, Columbia Missouri 65211, USA.

\begin{abstract}
This report summarizes the results of X-ray diffraction analyses of cuttings samples (1-4 mm diameter) from Integrated Ocean Drilling Program Expedition 338 Hole C0002F, located offshore southwest Japan. We analyzed 37 specimens ( $<2 \mu \mathrm{m}$ size fraction) from the upper Nankai accretionary prism, collected between 1190 and 1990 meters below seafloor. Smectite is generally the most abundant mineral in the clay-size fraction. Within lithologic Unit IV, smectite in the bulk sediment averages $25.1 \mathrm{wt} \%$ (standard deviation $=3.6)$, whereas illite and kaolinite + chlorite average 18.9 (standard deviation $=2.0$ ) and $11.3 \mathrm{wt} \%$ (standard deviation $=$ 2.3), respectively. Within Unit $\mathrm{V}$, smectite in the bulk sediment decreases to an average of $21.8 \mathrm{wt} \%$ (standard deviation $=2.8$ ) and values of illite and kaolinite + chlorite average 21.8 (standard deviation $=3.5$ ) and $14.1 \mathrm{wt} \%$ (standard deviation $=3.5$ and 2.4 ), respectively. The expandability of illite/smectite averages $69 \%$, and values decrease downhole. The proportion of illite in illite/ smectite mixed-layer clays averages $25 \%$, and those values increase downhole. Values of illite crystallinity index (average $=$ $0.52 \Delta^{\circ} 2 \theta$ ) are consistent with detrital source areas exposed to advanced levels of diagenesis and anchizone metamorphism.
\end{abstract}

\section{Introduction}

The Nankai Trough region, offshore southwest Japan (Fig. F1), has been sampled by scientific ocean drilling several times over the past four decades (Karig, Ingle, et al., 1975; Kagami, Karig, Coulbourn, et al., 1986; Shipboard Scientific Party, 1991, 2001). The latest drilling efforts are part of the Nankai Trough Seismogenic Zone Experiment (NanTroSEIZE) (Ashi et al., 2009; Screaton et al., 2009; Tobin et al., 2009; Underwood et al., 2010; Expedition 333 Scientists, 2012; also see the "Expedition 338 summary" chapter [Strasser et al., 2014a]). Previous investigators demonstrated that hemipelagic mud(stones) throughout the Nankai region change in composition largely as a function of depositional age (Cook et al., 1975; Chamley, 1980; Chamley et al., 1986; Underwood et al., 1993a, 1993b; Masuda et al., 1996, 2001; Steurer and Underwood, 2003; Underwood and Steurer, 2003; Guo and Underwood, 2012; Underwood and Guo, 2013). As a rule, deposits during the Miocene were enriched in smectite, whereas proportions of detrital illite and chlorite increased steadily during the Pliocene and Quaternary. 
Integrated Ocean Drilling Program (IODP) Site C0002 is located near the seaward edge of Kumano Basin (Fig. F1). IODP Expedition 338 extended Hole C0002F by riser drilling through the upper accretionary prism to 2004 meters below seafloor (mbsf) (see the "Expedition 338 summary" chapter [Strasser et al., 2014a]). The sampled interval contains nannofossils that are Miocene in age (>5.59 Ma). The common lithology is clayey siltstone (hemipelagic mudstone), with variable percentages of medium silt to fine sand (turbidites). A lithologic boundary between Units IV and V occurs at 1740 mbsf, as defined by a sharp reduction of sandstone content (Fig. F2). Stratigraphic details are obscured, however, by drilling technology that placed logging tools between a $12^{1 / 4}$ inch drill bit at the base of the bottom-hole assembly and a 20 inch reamer bit above. That configuration of two cutting tools resulted in thorough mixing of cuttings over a vertical interval of at least $43.8 \mathrm{~m}$.

One of the goals of NanTroSEIZE has been to document the abundance and hydration state of clay minerals (especially the smectite group) within accreted Nankai strata. That task is important because of the clay's likely influence on fluid production within the accretionary prism, as well as along the landward-dipping plate interface (e.g., Saffer et al., 2008). This report summarizes the results of X-ray diffraction (XRD) analyses of 37 cuttings samples extracted from Hole C0002F. We focus on common clay minerals (smectite, illite, chlorite, and kaolinite) and on indicators of clay diagenesis.

\section{Methods}

\section{Sample preparation}

All of the samples analyzed in this study were selected from cuttings measuring 1-4 mm in effective diameter (concentrated by wet sieving). Each extracted interval of cuttings included a companion specimen for shipboard bulk-powder XRD, which provided estimates of the relative abundance of total clay minerals, quartz, feldspar, and calcite (see the "Site C0002" chapter [Strasser et al., 2014b]). Isolation of the clay-size fraction for XRD analyses began with air-drying and gentle hand-crushing of the mudstone with mortar and pestle, after which specimens were immersed in $3 \% \mathrm{H}_{2} \mathrm{O}_{2}$ for at least $24 \mathrm{~h}$ to digest organic matter. We added $\sim 250 \mathrm{~mL}$ of Na-hexametaphosphate solution (concentration of $4 \mathrm{~g} / 1000$ $\mathrm{mL}$ distilled $\mathrm{H}_{2} \mathrm{O}$ ) and inserted the beakers into an ultrasonic bath for several minutes to promote disaggregation and deflocculation. This step (and additional soaking) was repeated until visual inspection indicated complete disaggregation. Washing consisted of two passes through a centrifuge (8200 revolutions per minute [rpm] for $25 \mathrm{~min} ; \sim 6000 \mathrm{~g}$ ) with resuspension in distilled-deionized water after each pass. After transferring the suspended sediment to a $60 \mathrm{~mL}$ plastic bottle, each sample was resuspended by vigorous shaking and a 2 min application of a sonic cell probe. The clay-size splits $(<2 \mu \mathrm{m}$ equivalent settling diameter) were then separated by centrifugation (1000 rpm for $2.4 \mathrm{~min} ; ~ 320 \mathrm{~g}$ ). Oriented clay aggregates were prepared using the filter-peel method (Moore and Reynolds, 1989) and $0.45 \mu \mathrm{m}$ membranes. We saturated the clay aggregates with ethylene glycol vapor using a closed vapor chamber heated to $60^{\circ} \mathrm{C}$ for at least $24 \mathrm{~h}$ prior to XRD analysis.

\section{X-ray diffraction}

Our analyses of the cuttings samples from Expedition 338 were completed at the New Mexico Bureau of Geology and Mineral Resources using a Panalytical X'Pert Pro diffractometer with $\mathrm{Cu}$ anode. Scans of oriented clay aggregates were run at generator settings of $45 \mathrm{kV}$ and $40 \mathrm{~mA}$. The continuous scans cover an angular range of $3^{\circ}$ to $26.5^{\circ} 2 \theta$ with a scan step time of $1.6 \mathrm{~s}$ and step size of $0.01^{\circ} 2 \theta$. Slits were 1.0 (divergence) and $0.1 \mathrm{~mm}$ (receiving), and the sample holder was spinning. We processed the digital data using MacDiff software (version 4.2.5) to establish a baseline of intensity, smooth counts, correct peak positions offset by misalignment of the detector (using the quartz [100] peak at $20.95^{\circ} 2 \theta$; dvalue $=4.24 \AA$ ), and calculate integrated peak areas (total counts). This program also calculated peak width at half height.

\section{Calculations of mineral abundance}

The most accurate analytical methods for XRD analyses require calibration with internal standards, use of single-line reference intensity ratios, and some fairly elaborate sample preparation steps to create optimal random particle orientations (e.g., Środoń et al., 2001; Omotoso et al., 2006). Our primary goal throughout the NanTroSEIZE project has been to obtain accurate values for the clay-size fraction from a large suite of samples. To accomplish that goal efficiently, we recorded the integrated areas of a broad smectite (001) peak centered at $\sim 5.3^{\circ} 2 \theta$ (d-value $=$ $16.5 \AA$ ), the illite $(001)$ peak at $\sim 8.9^{\circ} 2 \theta$ (d-value $=9.9$ $\AA)$, the composite chlorite (002) + kaolinite (001) peak at $12.5^{\circ} 2 \theta(\mathrm{d}$-value $=7.06 \AA)$, and the quartz (100) peak at $20.85^{\circ} 2 \theta(\mathrm{d}$-value $=4.26 \AA$ ). We then applied a matrix of singular value decomposition (SVD) normalization factors (Table T1), calculated af- 
ter analyzing standard mineral mixtures (Underwood et al., 2003). Those standards consisted of smectite + illite + chlorite + quartz. The average errors using this method were $3.9 \%$ for smectite, $1.0 \%$ for illite, $1.9 \%$ for chlorite, and $1.6 \%$ for quartz. The kaolinite (001) and chlorite (002) reflections overlap almost completely, so we followed a refined version of the Biscaye (1964) method, as documented by Guo and Underwood (2011). The average error of accuracy for the chlorite/kaolinite ratio is $2.6 \%$. To calculate the abundance of individual clay minerals in the bulk mudstone, we multiply each relative percentage value among the clay minerals (where smectite + illite + chlorite + kaolinite $=100 \%$ ) by the percentage of total clay minerals within the bulk powder (where total clay minerals + quartz + feldspar + calcite $=100 \%$ ), as determined by shipboard XRD analyses of collocated specimens (see the "Site C0002" chapter [Strasser et al., 2014b]). To facilitate direct comparisons with other published data sets from the region, we also report the weighted peak area percentages for smectite, illite, and chlorite + kaolinite using Biscaye (1965) weighting factors $(1 \times$ smectite, $4 \times$ illite, and $2 \times$ chlorite + kaolinite). Errors of accuracy using that method can be substantially greater $( \pm 10 \%$ or more) as compared to SVD normalization factors (Underwood et al., 2003).

For documentation of clay diagenesis, we utilized the saddle/peak method of Rettke (1981) to calculate percent expandability of smectite and illite/smectite mixed-layer clay. This method is sensitive to the proportions of discrete illite versus illite/smectite mixedlayer clay; we chose the curve for 1:1 mixtures of discrete illite and illite/smectite. A complementary measure of the proportion of illite in the illite/smectite mixed-layer phase considers the center peak position (2 $\theta$ angle) of the $(002 / 003)$ peak (following Moore and Reynolds, 1989), using the quartz (100) peak to correct for misalignment of the detector and/ or sample holder. We also report illite crystallinity (Kübler) index as values of peak width at half height $\left(\Delta^{\circ} 2 \theta\right)$ for the (001) reflection.

\section{Results}

Table T2 shows the peak-area values (total counts) for common minerals in the clay-size fraction, segregated by lithologic unit. We also tabulated the values of mineral abundance (wt\%) calculated by SVD normalization factors (Fig. F3) and by Biscaye (1965) peak-area weighting factors (Table T2). The peak intensities for four additional specimens were too low to generate reliable results, so those values were omitted. Relative abundances of clay-size smectite within Unit IV range from 55 to $30 \mathrm{wt} \%$, with a mean $(\mu)$ of $44.3 \mathrm{wt} \%$ and a standard deviation (s) of 6.3. Values for illite in the clay-size fraction range from 42 to $29 \mathrm{wt} \%(\mu=33.4 ; s=2.7)$. Percentages of kaolinite + chlorite in Unit IV range from 26 to 12 $\mathrm{wt} \%(\mu=19.9 ; \mathrm{s}=3.8)$; in all cases, chlorite is the dominant mineral over kaolinite. Percentages of clay-size quartz average only $2.5 \mathrm{wt} \%(\mathrm{~s}=2.5)$. Within Unit $\mathrm{V}$, the clay-size smectite ranges from 44 to $28 \mathrm{wt} \%(\mu=36.7 ; \mathrm{s}=6.2)$. Illite ranges from 55 to $32 \mathrm{wt} \%(\mu=37.6$; $s=4.7)$, whereas kaolinite + chlorite ranges from 36 to $19 \mathrm{wt} \%(\mu=23.9 ; s=2.6)$. The average percentage of clay-size quartz is only 1.8 wt $\%$.

Figure F4 illustrates how relative mineral abundances within the bulk sediment change with depth. Bulk sediment smectite values within Unit IV range from 33 to $19 \mathrm{wt} \%(\mu=25.1 ; s=3.6)$. Those percentages are significantly lower than what Underwood and Guo (2013) documented from coeval (5-6 Ma) Miocene strata at IODP Sites C0011 and C0012 in Shikoku Basin (i.e., the Nankai subduction inputs) (Fig. F1). Illite in the bulk sediment of Unit IV ranges from 25 to $15 \mathrm{wt} \%(\mu=18.9 ; \mathrm{s}=2.0)$, and kaolinite + chlorite ranges from 17 to $7 \mathrm{wt} \%(\mu=11.3 ; \mathrm{s}=2.3)$. Within Unit $\mathrm{V}$, smectite within bulk sediment ranges from 26 to $16 \mathrm{wt} \%(\mu=21.8 ; \mathrm{s}=2.8)$. Illite in the bulk sediment ranges from 27 to $16 \mathrm{wt} \%(\mu=21.8$; $\mathrm{s}$ $=3.5$ ), and kaolinite + chlorite ranges from 18 to 11 wt $\%(\mu=14.1 ; s=2.4)$.

Indicators of clay diagenesis are tabulated in Table T3 and plotted in Figure F5. Illite crystallinity (Kübler) indexes range from $0.67 \Delta^{\circ}$ to $0.41 \Delta^{\circ} 2 \theta$, with an average value of $0.52 \Delta^{\circ} 2 \theta$. As a frame of reference, the boundary between advanced diagenesis and anchizone metamorphism is set at $0.52 \Delta^{\circ} 2 \theta$, and the limit for epizone metamorphism (incipient greenschist facies) is $0.32 \Delta^{\circ} 2 \theta$ (Warr and Mählmann, 2015). The expandability of illite/smectite mixedlayer clays ranges from $89 \%$ to $59 \%$, with an average value of $68 \%(s=6.9)$. The proportion of illite in illite/smectite mixed-layer clays ranges from $6 \%$ to $49 \%$, with an average value of $25 \%(\mathrm{~s}=8.5)$. Values are scattered, but we note an increase in the levels of diagenesis with increasing depth (Fig. F5).

\section{Acknowledgments}

This research used samples provided by the Integrated Ocean Drilling Program (IODP). We thank the Mantle Quest Japan (MQJ) drilling crew, Marine Works Japan (MWJ) laboratory technicians, and scientists aboard the D/V Chikyu for their dedicated assistance during IODP Expedition 338. Funding was 
granted by the Consortium for Ocean Leadership, U.S. Science Support Program (task order T338B58). Nolan Walla assisted with sample preparation.

\section{References}

Ashi, J., Lallemant, S., Masago, H., and the Expedition 315 Scientists, 2009. Expedition 315 summary. In Kinoshita, M., Tobin, H., Ashi, J., Kimura, G., Lallemant, S., Screaton, E.J., Curewitz, D., Masago, H., Moe, K.T., and the Expedition 314/315/316 Scientists, Proceedings of the Integrated Ocean Drilling Program, 314/315/316: Washington, DC (Integrated Ocean Drilling Program Management International, Inc.). http://dx.doi.org/ 10.2204/iodp.proc.314315316.121.2009

Biscaye, P.E., 1964. Distinction between kaolinite and chlorite in recent sediments by X-ray diffraction. American Mineralogist, 49:1281-1289.

Biscaye, P.E., 1965. Mineralogy and sedimentation of recent deep-sea clay in the Atlantic Ocean and adjacent seas and oceans. Geological Society of America Bulletin, 76(7):803-831. http://dx.doi.org/10.1130/00167606(1965)76[803:MASORD]2.0.CO;2

Chamley, H., 1980. Clay sedimentation and paleoenvironment in the Shikoku Basin since the middle Miocene (Deep Sea Drilling Project Leg 58, North Philippine Sea). In Klein, G. de V., Kobayashi, K., et al., Initial Reports of the Deep Sea Drilling Project, 58:

Washington, DC (U.S. Govt. Printing Office), 669-678. http://dx.doi.org/10.2973/dsdp.proc.58.118.1980

Chamley, H., Cadet, J.-P., and Charvet, J., 1986. Nankai Trough and Japan Trench late Cenozoic paleoenvironments deduced from clay mineralogic data. In Kagami, H., Karig, D.E., Coulbourn, W.T., et al., Initial Reports of the Deep Sea Drilling Project, 87: Washington, DC (U.S. Govt. Printing Office), 633-641. http:// dx.doi.org/10.2973/dsdp.proc.87.113.1986

Cook, H.E., Zemmels, I., and Matti, J.C., 1975. X-ray mineralogy data, far western Pacific, Leg 31 Deep Sea Drilling Project. In Karig, D.E., Ingle, J.C., Jr., et al., Initial Reports of the Deep Sea Drilling Project, 31: Washington (U.S. Govt. Printing Office), 883-895. http:// dx.doi.org/10.2973/dsdp.proc.31.app.1975

Expedition 333 Scientists, 2012. Expedition 333 summary. In Henry, P., Kanamatsu, T., Moe, K., and the Expedition 333 Scientists, Proceedings of the Integrated Ocean Drilling Program, 333: Tokyo (Integrated Ocean Drilling Program Management International, Inc.). http:// dx.doi.org/10.2204/iodp.proc.333.101.2012

Guo, J., and Underwood, M.B., 2011. Data report: refined method for calculating percentages of kaolinite and chlorite from X-ray diffraction data, with application to the Nankai margin of southwest Japan. In Kinoshita, M., Tobin, H., Ashi, J., Kimura, G., Lallemant, S., Screaton, E.J., Curewitz, D., Masago, H., Moe, K.T., and the Expedition 314/315/316 Scientists, Proceedings of the Integrated Ocean Drilling Program, 314/315/316: Washington, DC (Integrated Ocean Drilling Program Man- agement International, Inc.). http://dx.doi.org/ 10.2204/iodp.proc.314315316.201.2011

Guo, J., and Underwood, M.B., 2012. Data report: clay mineral assemblages from the Nankai Trough accretionary prism and the Kumano Basin, IODP Expeditions 315 and 316, NanTroSEIZE Stage 1. In Kinoshita, M., Tobin, H., Ashi, J., Kimura, G., Lallemant, S., Screaton, E.J., Curewitz, D., Masago, H., Moe, K.T., and the Expedition $314 / 315 / 316$ Scientists, Proceedings of the Integrated Ocean Drilling Program, 314/315/316: Washington, DC (Integrated Ocean Drilling Program Management International, Inc.). http://dx.doi.org/10.2204/ iodp.proc.314315316.202.2012

Kagami, H., Karig, D.E., Coulbourn, W.T., et al., 1986. Initial Reports of the Deep Sea Drilling Project, 87: Washington, DC (U.S. Govt. Printing Office). http://dx.doi.org/ 10.2973/dsdp.proc.87.1986

Karig, D.E., Ingle, J.C., Jr., et al., 1975. Initial Reports of the Deep Sea Drilling Project, 31: Washington, DC (U.S. Govt. Printing Office). http://dx.doi.org/10.2973/ dsdp.proc.31.1975

Masuda, H., O'Neil, J.R., Jiang, W.-T., and Peacor, D.R., 1996. Relation between interlayer composition of authigenic smectite, mineral assemblages, $\mathrm{I} / \mathrm{S}$ reaction rate and fluid composition in silicic ash of the Nankai Trough. Clays and Clay Minerals, 44(4):443-459. http:// dx.doi.org/10.1346/CCMN.1996.0440402

Masuda, H., Peacor, D.R., and Dong, H., 2001. Transmission electron microscopy study of conversion of smectite to illite in mudstones of the Nankai Trough: contrast with coeval bentonites. Clays and Clay Minerals, 49(2):109-118. http://dx.doi.org/10.1346/ CCMN.2001.0490201

Moore, D.M., and Reynolds, R.C., Jr., 1989. Quantitative analysis. In Moore, D.M., and Reynolds, R.C., Jr. (Eds.), $X$-Ray Diffraction and the Identification and Analysis of Clay Minerals: New York (Oxford Univ. Press USA), 272309.

Omotoso, O., McCarty, D.K., Hillier, S., and Kleeberg, R., 2006. Some successful approaches to quantitative mineral analysis as revealed by the 3rd Reynolds Cup contest. Clays and Clay Minerals, 54(6):748-760. http:// dx.doi.org/10.1346/CCMN.2006.0540609

Rettke, R.C., 1981. Probable burial diagenetic and provenance effects on Dakota Group clay mineralogy, Denver Basin. Journal of Sedimentary Petrology, 51(2):541-551. http://dx.doi.org/10.1306/212F7CCF-2B24-11D78648000102C1865D

Saffer, D.M., Underwood, M.B., and McKiernan, A.W., 2008. Evaluation of factors controlling smectite transformation and fluid production in subduction zones: application to the Nankai Trough. Island Arc, 17(2):208230. http://dx.doi.org/10.1111/j.14401738.2008.00614.x

Screaton, E.J., Kimura, G., Curewitz, D., and the Expedition 316 Scientists, 2009. Expedition 316 summary. In Kinoshita, M., Tobin, H., Ashi, J., Kimura, G., Lallemant, S., Screaton, E.J., Curewitz, D., Masago, H., Moe, K.T., and the Expedition 314/315/316 Scientists, Pro- 
ceedings of the Integrated Ocean Drilling Program, 314/315/ 316: Washington, DC (Integrated Ocean Drilling Program Management International, Inc.). http:// dx.doi.org/10.2204/iodp.proc.314315316.131.2009

Shipboard Scientific Party, 1991. Site 808. In Taira, A., Hill, I., Firth, J.V., et al., Proceedings of the Ocean Drilling Program, Initial Reports, 131: College Station, TX (Ocean Drilling Program), 71-269. http://dx.doi.org/10.2973/ odp.proc.ir.131.106.1991

Shipboard Scientific Party, 2001. Leg 190 summary. In Moore, G.F., Taira, A., Klaus, A., et al., Proceedings of the Ocean Drilling Program, Initial Reports, 190: College Station, TX (Ocean Drilling Program), 1-87. http:// dx.doi.org/10.2973/odp.proc.ir.190.101.2001

Środoń, J., Drits, V.A., McCarty, D.K., Hsieh, J.C.C., and Eberl, D.D., 2001. Quantitative X-ray diffraction analysis of clay-bearing rocks from random preparations. Clays and Clay Minerals, 49(6):514-528. http:// ccm.geoscienceworld.org/cgi/content/abstract/49/ $6 / 514$

Steurer, J.F., and Underwood, M.B., 2003. Clay mineralogy of mudstones from the Nankai Trough reference Sites 1173 and 1177 and frontal accretionary prism Site 1174. In Mikada, H., Moore, G.F., Taira, A., Becker, K., Moore, J.C., and Klaus, A. (Eds.), Proceedings of the Ocean Drilling Program, Scientific Results, 190/196: College Station, TX (Ocean Drilling Program), 1-37. http://dx.doi.org/ 10.2973/odp.proc.sr.190196.211.2003

Strasser, M., Dugan, B., Kanagawa, K., Moore, G.F., Toczko, S., Maeda, L., Kido, Y., Moe, K.T., Sanada, Y., Esteban, L., Fabbri, O., Geersen, J., Hammerschmidt, S., Hayashi, H., Heirman, K., Hüpers, A., Jurado Rodriguez, M.J., Kameo, K., Kanamatsu, T., Kitajima, H., Masuda, H., Milliken, K., Mishra, R., Motoyama, I., Olcott, K., Oohashi, K., Pickering, K.T., Ramirez, S.G., Rashid, H., Sawyer, D., Schleicher, A., Shan, Y., Skarbek, R., Song, I., Takeshita, T., Toki, T., Tudge, J., Webb, S., Wilson, D.J., Wu, H.-Y., and Yamaguchi, A., 2014a. Expedition 338 summary. In Strasser, M., Dugan, B., Kanagawa, K., Moore, G.F., Toczko, S., Maeda, L., and the Expedition 338 Scientists, Proceedings of the Integrated Ocean Drilling Program, 338: Yokohama (Integrated Ocean Drilling Program). http:// dx.doi.org/10.2204/iodp.proc.338.101.2014

Strasser, M., Dugan, B., Kanagawa, K., Moore, G.F., Toczko, S., Maeda, L., Kido, Y., Moe, K.T., Sanada, Y., Esteban, L., Fabbri, O., Geersen, J., Hammerschmidt, S., Hayashi, H., Heirman, K., Hüpers, A., Jurado Rodriguez, M.J., Kameo, K., Kanamatsu, T., Kitajima, H., Masuda, H., Milliken, K., Mishra, R., Motoyama, I., Olcott, K., Oohashi, K., Pickering, K.T., Ramirez, S.G., Rashid, H., Sawyer, D., Schleicher, A., Shan, Y., Skarbek, R., Song, I., Takeshita, T., Toki, T., Tudge, J., Webb, S., Wilson, D.J., Wu, H.-Y., and Yamaguchi, A., 2014b. Site C0002. In Strasser, M., Dugan, B., Kanagawa, K., Moore, G.F., Toczko, S., Maeda, L., and the Expedition 338 Scientists, Proceedings of the Integrated Ocean Drilling Program, 338: Yokohama (Integrated Ocean Drilling Program). http:// dx.doi.org/10.2204/iodp.proc.338.103.2014
Tobin, H., Kinoshita, M., Ashi, J., Lallemant, S., Kimura, G., Screaton, E.J., Moe, K.T., Masago, H., Curewitz, D., and the Expedition 314/315/316 Scientists, 2009. NanTroSEIZE Stage 1 expeditions: introduction and synthesis of key results. In Kinoshita, M., Tobin, H., Ashi, J., Kimura, G., Lallemant, S., Screaton, E.J., Curewitz, D., Masago, H., Moe, K.T., and the Expedition 314/315/316 Scientists, Proceedings of the Integrated Ocean Drilling Program, 314/315/316: Washington, DC (Integrated Ocean Drilling Program Management International, Inc.). http://dx.doi.org/10.2204/ iodp.proc.314315316.101.2009

Underwood, M.B., Basu, N., Steurer, J., and Udas, S., 2003. Data report: normalization factors for semiquantitative X-ray diffraction analysis, with application to DSDP Site 297, Shikoku Basin. In Mikada, H., Moore, G.F., Taira, A., Becker, K., Moore, J.C., and Klaus, A. (Eds.), Proceedings of the Ocean Drilling Program, Scientific Results, 190/ 196: College Station, TX (Ocean Drilling Program), 128. http://dx.doi.org/10.2973/ odp.proc.sr.190196.203.2003

Underwood, M.B., and Guo, J., 2013. Data report: clay mineral assemblages in the Shikoku Basin, NanTroSEIZE subduction inputs, IODP Sites C0011 and C0012. In Saito, S., Underwood, M.B., Kubo, Y., and the Expedition 322 Scientists, Proceedings of the Integrated Ocean Drilling Program, 322: Tokyo (Integrated Ocean Drilling Program Management International, Inc.). http:// dx.doi.org/10.2204/iodp.proc.322.202.2013

Underwood, M.B., Orr, R., Pickering, K., and Taira, A., 1993a. Provenance and dispersal patterns of sediments in the turbidite wedge of Nankai Trough. In Hill, I.A., Taira, A., Firth, J.V., et al., Proceedings of the Ocean Drilling Program, Scientific Results, 131: College Station, TX (Ocean Drilling Program), 15-34. http://dx.doi.org/ 10.2973/odp.proc.sr.131.105.1993

Underwood, M.B., Pickering, K., Gieskes, J.M., Kastner, M., and Orr, R., 1993b. Sediment geochemistry, clay mineralogy, and diagenesis: a synthesis of data from Leg 131, Nankai Trough. In Hill, I.A., Taira, A., Firth, J.V., et al., Proceedings of the Ocean Drilling Program, Scientific Results, 131: College Station, TX (Ocean Drilling Program), 343-363. http://dx.doi.org/10.2973/ odp.proc.sr.131.137.1993

Underwood, M.B., Saito, S., Kubo, Y., and the Expedition 322 Scientists, 2010. Expedition 322 summary. In Saito, S., Underwood, M.B., Kubo, Y., and the Expedition 322 Scientists, Proceedings of the Integrated Ocean Drilling Program, 322: Tokyo (Integrated Ocean Drilling Program Management International, Inc.). http://dx.doi.org/ 10.2204/iodp.proc.322.101.2010

Underwood, M.B., and Steurer, J.F., 2003. Composition and sources of clay from the trench slope and shallow accretionary prism of Nankai Trough. In Mikada, H., Moore, G.F., Taira, A., Becker, K., Moore, J.C., and Klaus, A. (Eds.), Proceedings of the Ocean Drilling Program, Scientific Results, 190/196: College Station, TX (Ocean Drilling Program), 1-28. http://dx.doi.org/10.2973/ odp.proc.sr.190196.206.2003 
Warr, L.N., and Mählmann, R.F., 2015. Recommendations for Kübler Index standardization. Clay Minerals, 50(3):283-286. http://dx.doi.org/10.1180/claymin.2015.050.3.02
Initial receipt: 16 March 2016

Acceptance: 18 July 2016

Publication: 6 September 2016

MS 338-206 
Figure F1. Map of the Nankai Trough and Kumano Basin study area (NanTroSEIZE transect) with locations of Sites C0002, C0011, and C0012. The composition of sediment at Site C0002 is compared to coeval (late Miocene) deposits at Sites C0011 and C0012.

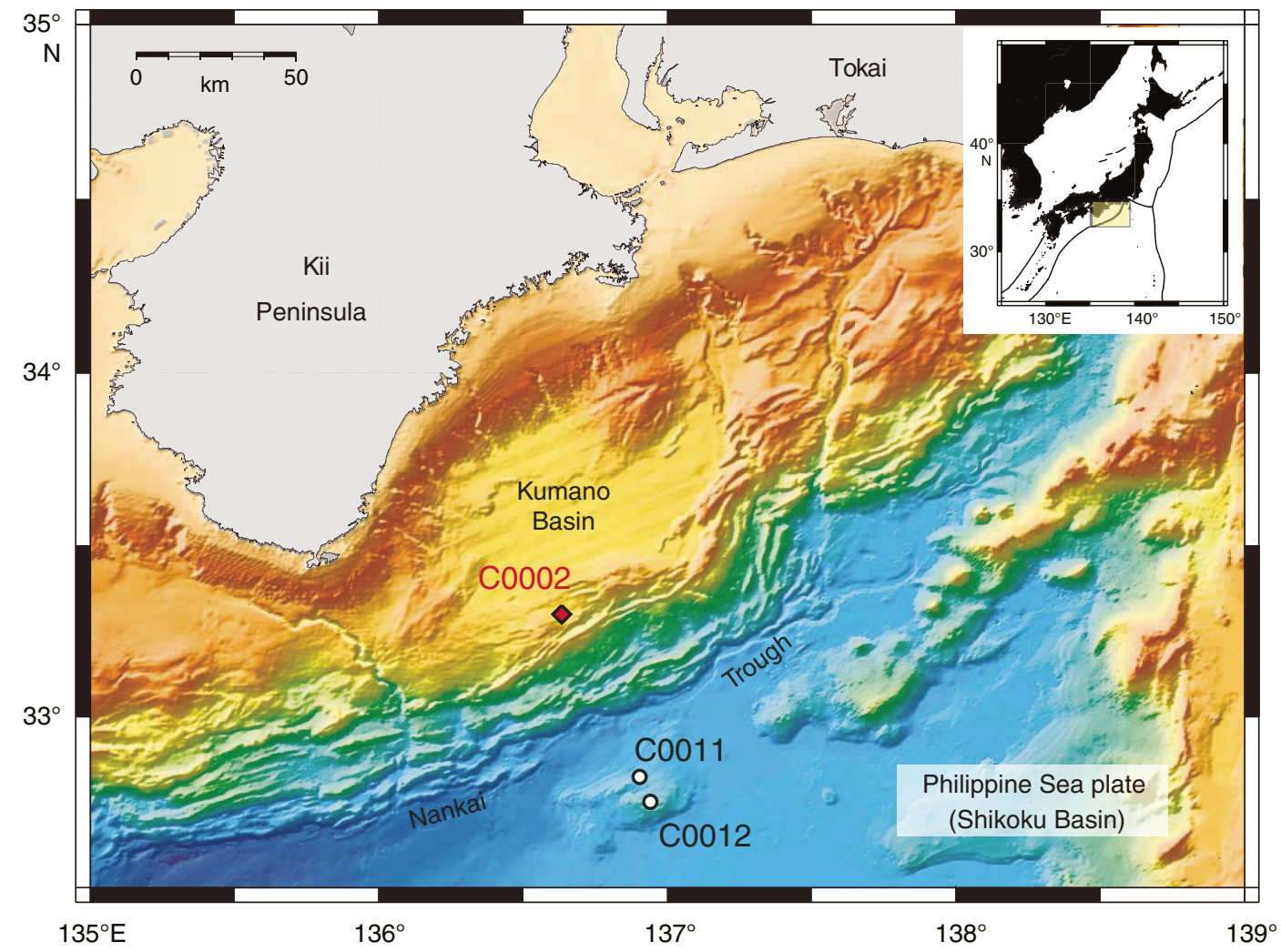


Figure F2. Seismic in-line section crossing Kumano Basin showing location of Site C0002 and lithologic units defined by shipboard analyses of cores and cuttings (see the "Expedition 338 summary" chapter [Strasser et al., 2014a]). LWD = logging while drilling, VE = vertical exaggeration.

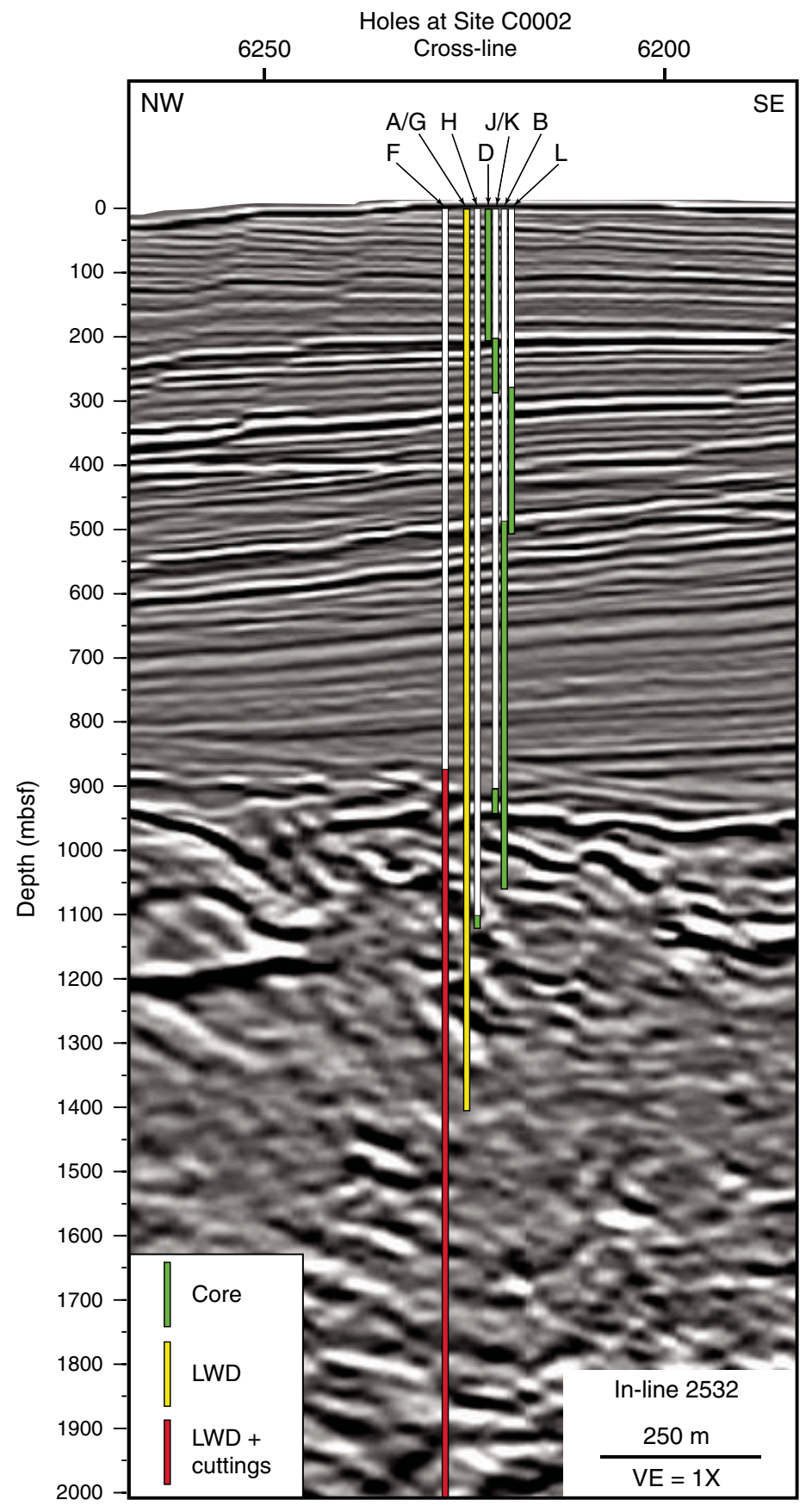

Core

Cuttings

Exps. 315 and 338

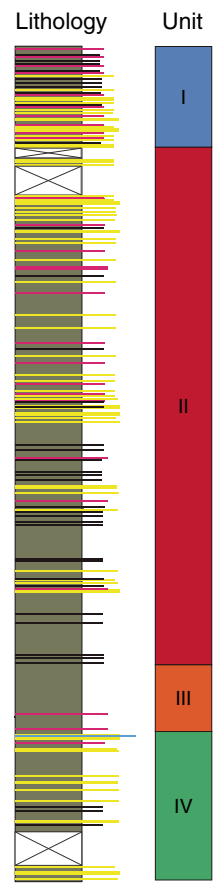

Exp. 338

\section{Lithology}

fraction

$0 \quad 1$ Unit

Cement

Unit

Silt
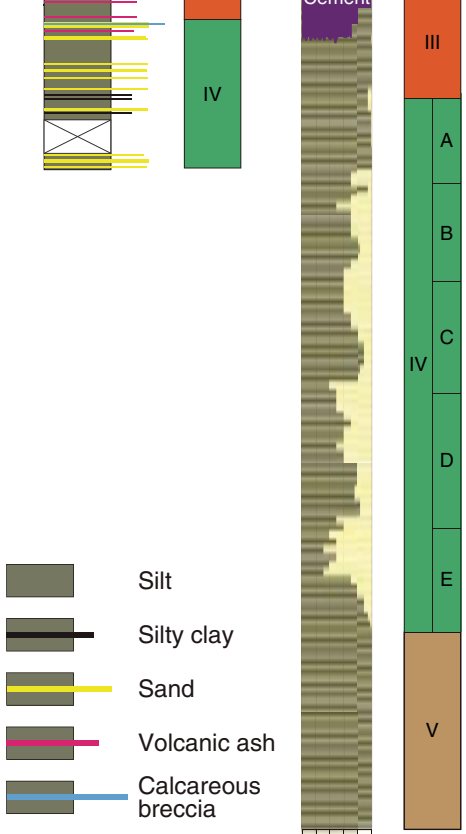
Figure F3. Calculated abundance (relative wt\%) of smectite, illite, chlorite, kaolinite, and quartz within the clay-size fraction of cuttings (1-4 mm) from Hole C0002F. Stratigraphic summary is from the "Expedition 338 summary" chapter (Strasser et al., 2014a).

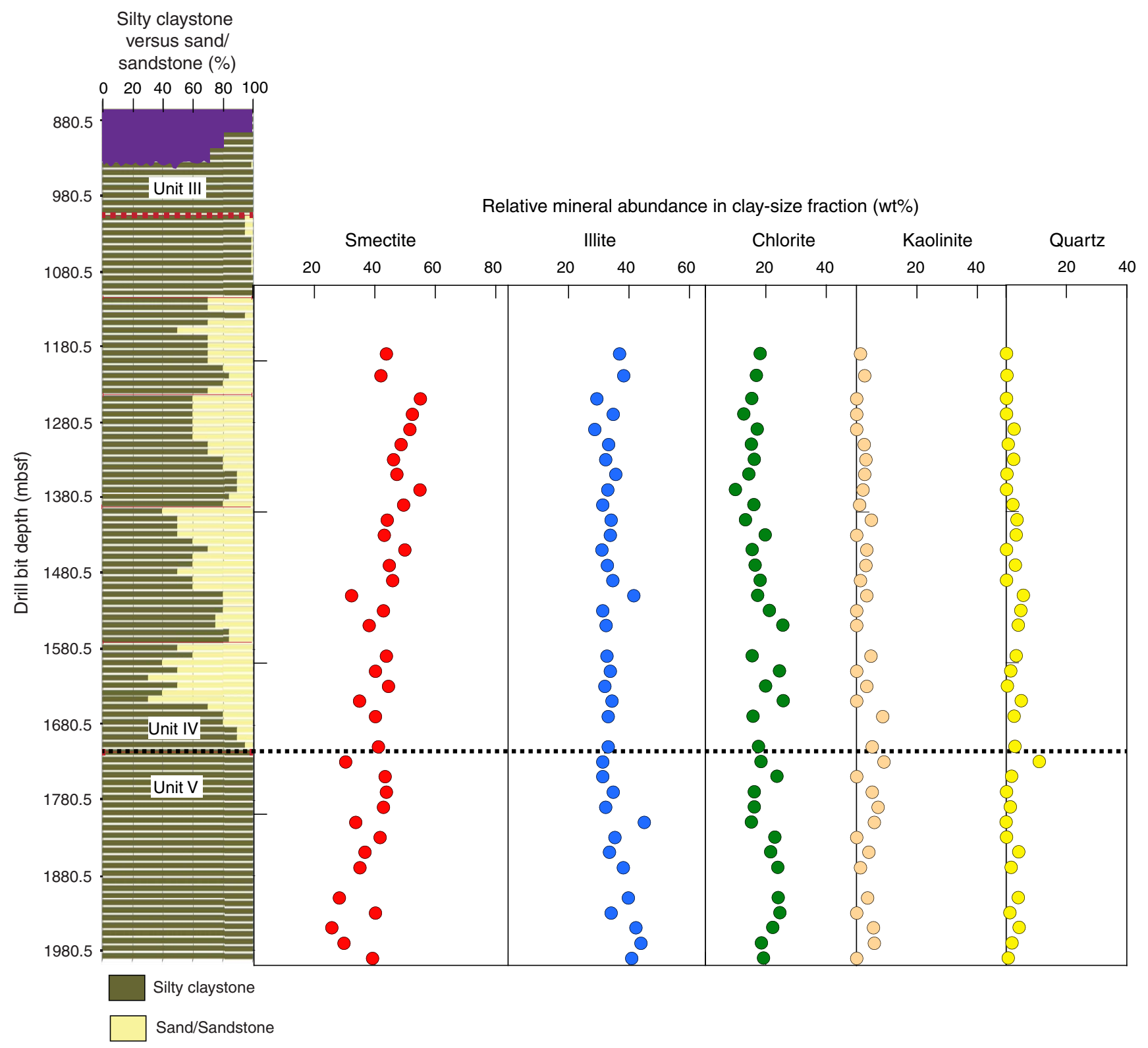


Figure F4. Calculated abundances (relative wt\%) of total clay minerals, smectite, illite, and chlorite + kaolinite within bulk sediment cuttings (1-4 mm) from Hole C0002F. Stratigraphic summary is from the "Expedition 338 summary" chapter (Strasser et al., 2014a).

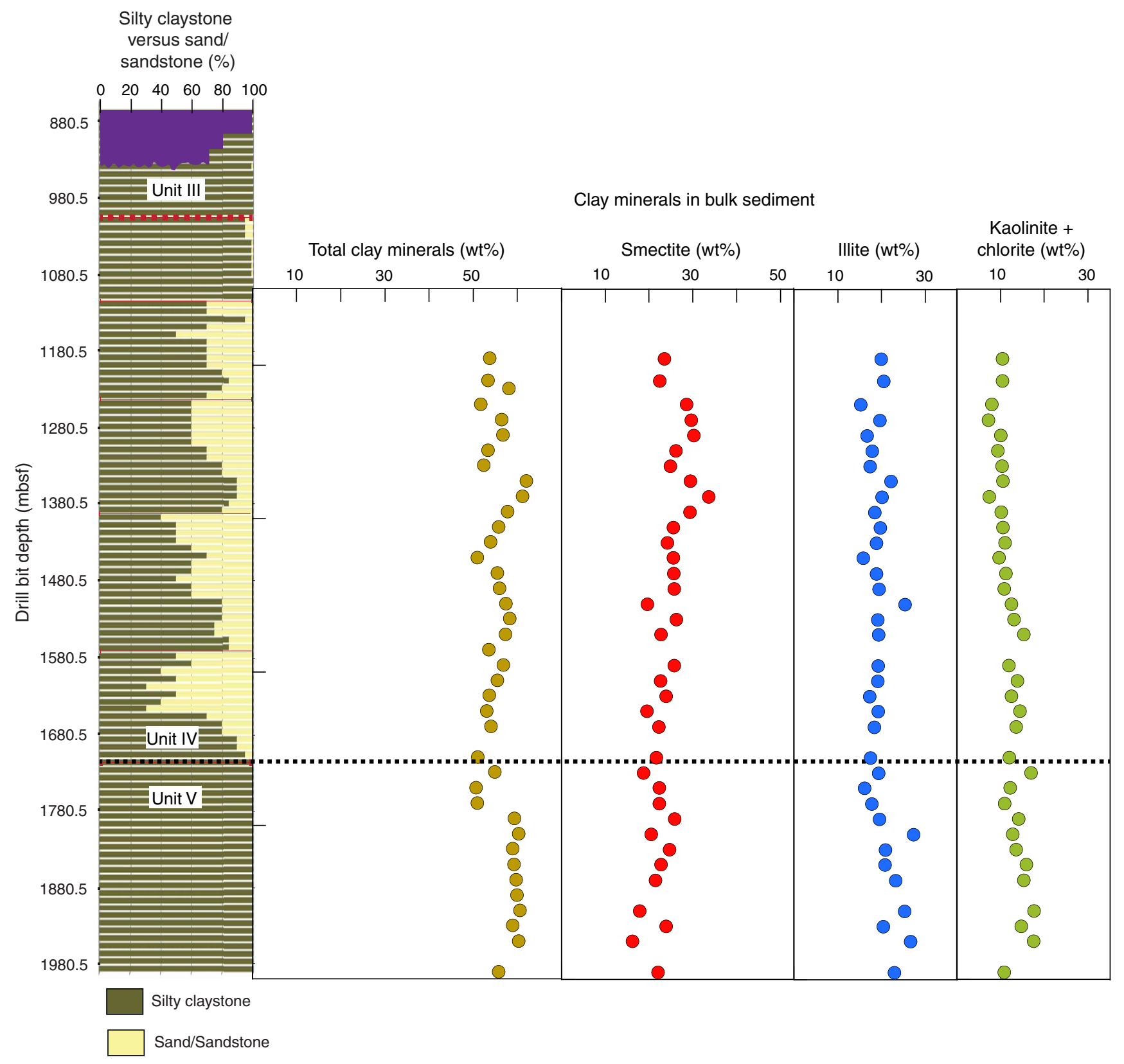


Figure F5. Illite/smectite (I/S) expandability, illite abundance in I/S mixed-layer clay, and illite crystallinity index within the clay-size fraction of cuttings $(1-4 \mathrm{~mm})$ from Hole C0002F. Dashed trend lines are qualitative.

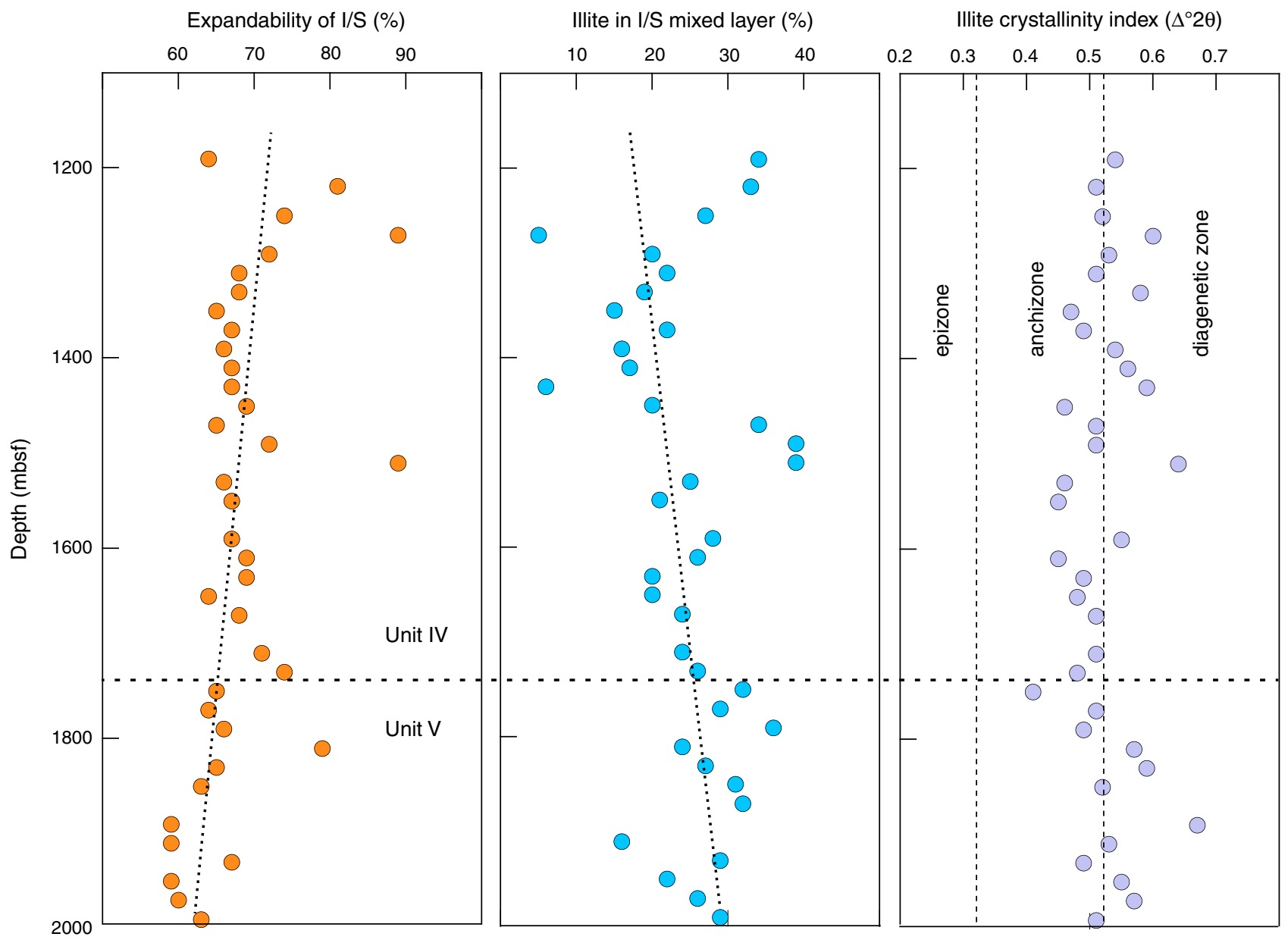


Table T1. Matrix of normalization factors derived from singular value decomposition and used to calculate relative mineral abundances in clay-size aggregates, Hole C0002F.

\begin{tabular}{lrrrr}
\hline \multirow{2}{*}{$\begin{array}{c}\text { Influencing } \\
\text { mineral }\end{array}$} & \multicolumn{4}{c}{ Target mineral in standard mixture } \\
\cline { 2 - 5 } & \multicolumn{1}{c}{ Smectite } & \multicolumn{1}{c}{ lllite } & \multicolumn{1}{c}{ Chlorite } & \multicolumn{1}{c}{ Quartz } \\
\hline Smectite & $7.4475294 \mathrm{E}-04$ & $-3.1953641 \mathrm{E}-05$ & $-7.5067212 \mathrm{E}-05$ & $-1.5661915 \mathrm{E}-04$ \\
Illite & $6.3114654 \mathrm{E}-05$ & $3.7866938 \mathrm{E}-03$ & $8.4222964 \mathrm{E}-05$ & $1.1769286 \mathrm{E}-04$ \\
Chlorite & $-3.5636057 \mathrm{E}-04$ & $-6.7378140 \mathrm{E}-05$ & $2.5121504 \mathrm{E}-03$ & $5.2290707 \mathrm{E}-05$ \\
Quartz & $9.3573136 \mathrm{E}-03$ & $3.6491468 \mathrm{E}-03$ & $3.2755411 \mathrm{E}-03$ & $1.4825645 \mathrm{E}-02$ \\
\hline
\end{tabular}


Table T2. Results of X-ray diffraction analyses ( $<2 \mu \mathrm{m}$ size fraction) for cuttings samples (1-4 mm), Hole C0002F.

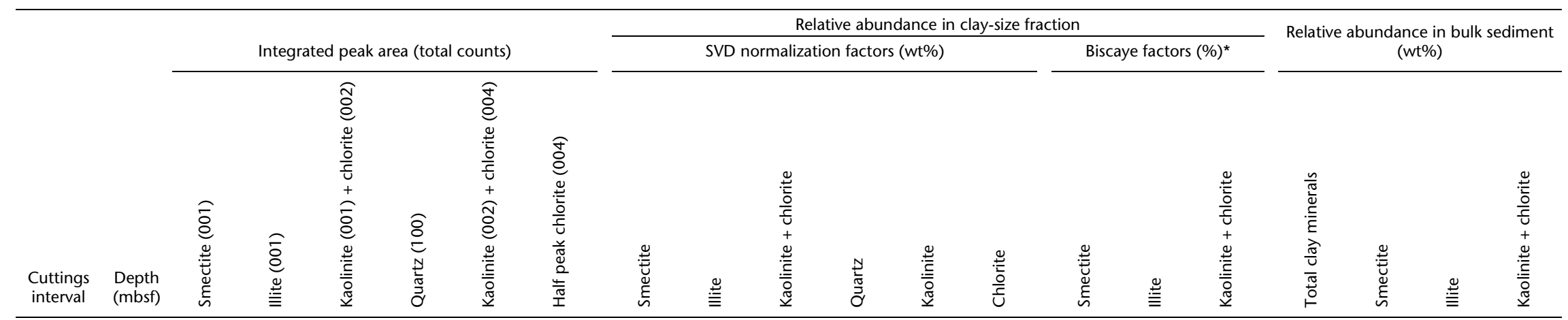

\section{8-C0002F-
Unit IV}

$\begin{array}{cccccccccccccc}82 & 1190.5 & 26424 & 4669 & 3978 & 220 & 2778 & 1328 & 43.7 & 36.8 & 19.3 & 0.2 & 1.2 & 18.1 \\ 86 & 1219.5 & 21392 & 4066 & 3336 & 166 & 2593 & 1170 & 42.0 & 38.3 & 19.4 & 0.3 & 2.7 & 16.8\end{array}$

$\begin{array}{llllllllllllll}86 & 1219.5 & 21392 & 4066 & 3336 & 166 & 2593 & 1170 & 42.0 & 38.3 & 19.4 & 0.3 & 2.7 & 16.8 \\ 96 & 1250.5 & 32558 & 3696 & 3372 & 271 & 2588 & 1292 & 55.1 & 29.3 & 15.4 & 0.2 & 0.0 & 15.4\end{array}$

$\begin{array}{lrllllllllllll}96 & 1250.5 & 32558 & 3696 & 3372 & 271 & 2588 & 1292 & 55.1 & 29.3 & 15.4 & 0.2 & 0.0 & 15.4 \\ 100 & 1270.5 & 32249 & 4574 & 2936 & 269 & 1895 & 969 & 52.4 & 34.7 & 12.7 & 0.2 & 0.0 & 12.7\end{array}$

$\begin{array}{lllllllllllll}100 & 1270.5 & 32249 & 4574 & 2936 & 269 & 1895 & 969 & 52.4 & 34.7 & 12.7 & 0.2 & 0.0 \\ 127.7 & 27847 & 3325 & 3306 & 338 & 2335 & 1176 & 51.6 & 28.6 & 17.1 & 2.7 & 0.0 & 17.1\end{array}$

$\begin{array}{llllllllllllll}104 & 1290.5 & 27847 & 3325 & 3306 & 338 & 2335 & 1176 & 51.6 & 28.6 & 17.1 & 2.7 & 0.0 & 17.1 \\ 108 & 1310.5 & 31030 & 4522 & 3948 & 301 & 3007 & 1352 & 48.6 & 33.2 & 17.5 & 0.7 & 2.5 & 15.1\end{array}$

$\begin{array}{llllllllllllll}112 & 1330.5 & 29404 & 4388 & 4236 & 347 & 3276 & 1451 & 46.2 & 32.2 & 19.2 & 2.5 & 3.1 & 16.1 \\ 116 & 1350.5 & 29158 & 4662 & 3662 & 268 & 2615 & 1163 & 47.3 & 35.6 & 16.9 & 0.3 & 2.6 & 14.3\end{array}$

$\begin{array}{rrrrrrrrrrrrrr}116 & 1350.5 & 29158 & 4662 & 3662 & 268 & 2615 & 1163 & 47.3 & 35.6 & 16.9 & 0.3 & 2.6 & 14.3 \\ 122 & 1370.5 & 43842 & 5547 & 3830 & 182 & 2341 & 1016 & 54.8 & 32.9 & 12.2 & 0.2 & 2.2 & 9.9\end{array}$

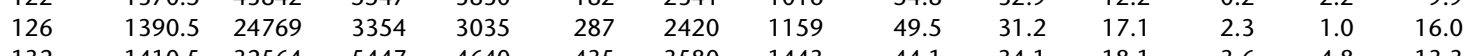

$\begin{array}{llllllllllllll}132 & 1410.5 & 32564 & 5447 & 4640 & 435 & 3580 & 1443 & 44.1 & 34.1 & 18.1 & 3.6 & 4.8 & 13.3\end{array}$

$\begin{array}{llllllllllllll}136 & 1430.5 & 33448 & 5642 & 5242 & 438 & 3650 & 1941 & 43.1 & 33.8 & 19.7 & 3.4 & 0.0 & 19.7\end{array}$

$\begin{array}{llllllllllllll}140 & 1450.5 & 30385 & 3987 & 4027 & 245 & 2628 & 1147 & 49.9 & 31.0 & 18.9 & 0.2 & 3.3 & 15.5 \\ 144 & 1470.5 & 28486 & 4489 & 4287 & 359 & 2625 & 1165 & 44.7 & 32.8 & 19.5 & 3.1 & 3.1 & 16.4\end{array}$

$\begin{array}{lllllllllllllll}144 & 1470.5 & 28486 & 4489 & 4287 & 359 & 2625 & 1165 & 44.7 & 32.8 & 19.5 & 3.1 & 3.1 & 16.4 \\ 150 & 1490.5 & 33565 & 5283 & 4854 & 232 & 3971 & 1895 & 45.9 & 34.6 & 19.4 & 0.2 & 1.3 & 18.1\end{array}$

$\begin{array}{llllllllllllll}155 & 1510.5 & 21361 & 6122 & 4548 & 380 & 2776 & 1228 & 32.2 & 41.6 & 20.4 & 5.7 & 3.3 & 17.2 \\ 161 & 1530.5 & 24835 & 3923 & 4212 & 373 & 3131 & 1668 & 42.8 & 31.2 & 21.2 & 4.8 & 0.0 & 21.2\end{array}$

$\begin{array}{llllllllllllll}161 & 1530.5 & 24835 & 3923 & 4212 & 373 & 3131 & 1668 & 42.8 & 31.2 & 21.2 & 4.8 & 0.0 & 21.2 \\ 167 & 1550.5 & 20722 & 3741 & 4596 & 291 & 3404 & 1927 & 38.1 & 32.4 & 25.6 & 4.0 & 0.0 & 25.6\end{array}$

$\begin{array}{llllllllllllll}177 & 1590.5 & 31102 & 4989 & 4917 & 403 & 4126 & 1713 & 43.8 & 32.7 & 20.2 & 3.3 & 4.7 & 15.5\end{array}$

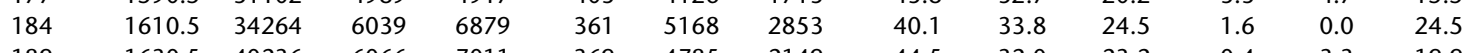

$\begin{array}{llllllllllllll}189 & 1630.5 & 40236 & 6066 & 7011 & 369 & 4785 & 2149 & 44.5 & 32.0 & 23.2 & 0.4 & 3.3 & 19.9\end{array}$

$\begin{array}{llllllllllllll}195 & 1650.5 & 25257 & 5316 & 6153 & 402 & 4537 & 2443 & 34.9 & 34.3 & 25.8 & 5.0 & 0.0 & 25.8 \\ 201 & 1670.5 & 29727 & 5171 & 5965 & 354 & 3919 & 1444 & 40.1 & 33.1 & 24.3 & 2.6 & 8.6 & 15.7\end{array}$

$\begin{array}{llllllllllllll}201 & 1670.5 & 29727 & 5171 & 5965 & 354 & 3919 & 1444 & 40.1 & 33.1 & 24.3 & 2.6 & 8.6 & 15.7 \\ 209 & 1710.5 & 36947 & 6335 & 6865 & 465 & 5017 & 2095 & 41.1 & 33.1 & 22.8 & 3.0 & 5.2 & 17.6\end{array}$

$\begin{array}{llllllllllllll}213 & 1730.5 & 10640 & 2532 & 3371 & 323 & 2944 & 1116 & 30.3 & 31.2 & 27.4 & 11.0 & 9.0 & 18.4\end{array}$

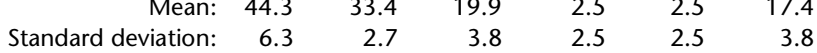

Unit $\mathrm{V}$

$\begin{array}{rllllllllllllll}\text { Unit V } & & & & & & & & & & & & \\ 217 & 1750.5 & 25195 & 3829 & 4586 & 274 & 3048 & 1675 & 43.4 & 31.3 & 23.6 & 1.8 & 0.0 & 23.6 & \\ 223 & 1770.5 & 30331 & 4954 & 4963 & 175 & 3161 & 1301 & 43.7 & 34.7 & 21.4 & 0.2 & 5.2 & 16.2 & \\ 229 & 1790.5 & 29102 & 4615 & 5295 & 307 & 3107 & 1205 & 42.8 & 32.3 & 23.3 & 1.5 & 7.1 & 16.2 & 5.9 \\ 233 & 1810.5 & 35576 & 9648 & 7113 & 243 & 4948 & 1968 & 33.7 & 45.0 & 21.1 & 0.1 & 5.9 & 15.2 & 40.9 \\ 238 & 1830.5 & 34256 & 5943 & 6164 & 222 & 4229 & 2209 & 41.7 & 35.3 & 22.9 & 0.2 & 0.0 & 22.9 & 45.2 \\ 250 & 1850.5 & 31783 & 6159 & 7322 & 459 & 5323 & 2360 & 36.7 & 33.5 & 25.7 & 4.2 & 4.1 & 21.6 & 45.7 \\ 255 & 1870.5 & 30565 & 6861 & 7022 & 321 & 4976 & 2399 & 35.1 & 38.1 & 25.1 & 1.7 & 1.3 & 23.9 \\ 265 & 1910.5 & 22623 & 6675 & 7039 & 339 & 4407 & 1993 & 28.2 & 39.8 & 27.8 & 4.1 & 3.7 & 24.1\end{array}$

$\begin{array}{llll}1910.5 & 22623 & 6675 & 7039\end{array}$ 


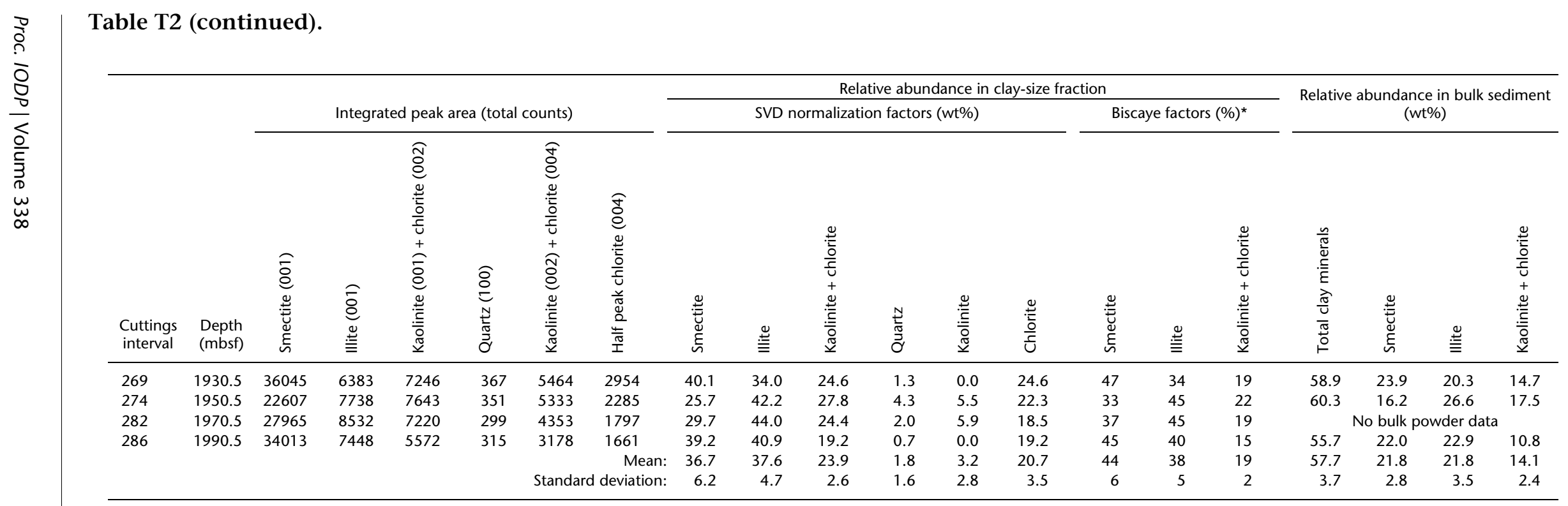

* = Biscaye (1965) peak area weighting factors are $1 \times$ smecite, $4 \times$ illite, and $2 \times$ chlorite + kaolinite. SVD = singular value decomposition. 
Table T3. Illite/smectite expandability values, illite abundance in illite/smectite (I/S) mixed-layer clay $(<2 \mu \mathrm{m}$ size fraction), and illite crystallinity index for cuttings samples (1-4 mm), Hole C0002F.

\begin{tabular}{|c|c|c|c|c|c|c|c|c|}
\hline $\begin{array}{c}\text { Cuttings } \\
\text { interval } \\
(\mathrm{cm})\end{array}$ & $\begin{array}{l}\text { Depth } \\
\text { (mbsf) }\end{array}$ & $\begin{array}{c}\text { S(001) } \\
\text { saddle } \\
(c p s)\end{array}$ & $\begin{array}{c}S(001) \\
\text { peak } \\
(c p s)\end{array}$ & $\begin{array}{l}\text { Saddle:peak } \\
\text { ratio }\end{array}$ & $\begin{array}{c}\text { Expandability } \\
(\%)\end{array}$ & $\begin{array}{c}\mathrm{I}(002)+\mathrm{S}(003) \\
\left({ }^{\circ} 2 \theta\right)\end{array}$ & $\begin{array}{c}\text { Illite in I/S } \\
(\%)\end{array}$ & $\begin{array}{l}\text { Crystallinity } \\
\text { index }\left(\Delta^{\circ} 2 \theta\right)\end{array}$ \\
\hline \multicolumn{9}{|c|}{ 338-C0002F- } \\
\hline 82 & 1190.5 & 213 & 319 & 0.67 & 64 & 16.05 & 34 & 0.54 \\
\hline 86 & 1219.5 & 56 & 173 & 0.32 & 81 & 16.04 & 33 & 0.51 \\
\hline 96 & 1250.5 & 132 & 294 & 0.45 & 74 & 15.97 & 27 & 0.52 \\
\hline 100 & 1270.5 & 50 & 240 & 0.21 & 89 & 15.74 & 5 & 0.60 \\
\hline 104 & 1290.5 & 125 & 264 & 0.47 & 72 & 15.89 & 20 & 0.53 \\
\hline 108 & 1310.5 & 190 & 342 & 0.56 & 68 & 15.91 & 22 & 0.51 \\
\hline 112 & 1330.5 & 212 & 371 & 0.57 & 68 & 15.88 & 19 & 0.58 \\
\hline 116 & 1350.5 & 235 & 373 & 0.63 & 65 & 15.84 & 15 & 0.47 \\
\hline 122 & 1370.5 & 303 & 511 & 0.59 & 67 & 15.91 & 22 & 0.49 \\
\hline 126 & 1390.5 & 182 & 303 & 0.60 & 66 & 15.85 & 16 & 0.54 \\
\hline 132 & 1410.5 & 232 & 398 & 0.58 & 67 & 15.86 & 17 & 0.56 \\
\hline 136 & 1430.5 & 243 & 417 & 0.58 & 67 & 15.75 & 6 & 0.59 \\
\hline 140 & 1450.5 & 200 & 370 & 0.54 & 69 & 15.89 & 20 & 0.46 \\
\hline 144 & 1470.5 & 221 & 351 & 0.63 & 65 & 16.05 & 34 & 0.51 \\
\hline 150 & 1490.5 & 159 & 332 & 0.48 & 72 & 16.12 & 39 & 0.51 \\
\hline 155 & 1510.5 & 32 & 160 & 0.20 & 89 & 16.12 & 39 & 0.64 \\
\hline 161 & 1530.5 & 189 & 314 & 0.60 & 66 & 15.95 & 25 & 0.46 \\
\hline 167 & 1550.5 & 160 & 275 & 0.58 & 67 & 15.90 & 21 & 0.45 \\
\hline 177 & 1590.5 & 208 & 356 & 0.58 & 67 & 15.98 & 28 & 0.55 \\
\hline 184 & 1610.5 & 188 & 352 & 0.53 & 69 & 15.96 & 26 & 0.45 \\
\hline 189 & 1630.5 & 252 & 466 & 0.54 & 69 & 15.89 & 20 & 0.49 \\
\hline 195 & 1650.5 & 215 & 324 & 0.66 & 64 & 15.89 & 20 & 0.48 \\
\hline 201 & 1670.5 & 200 & 360 & 0.56 & 68 & 15.94 & 24 & 0.51 \\
\hline 209 & 1710.5 & 180 & 360 & 0.50 & 71 & 15.93 & 24 & 0.51 \\
\hline 213 & 1730.5 & 50 & 112 & 0.45 & 74 & 15.96 & 26 & 0.48 \\
\hline 217 & 1750.5 & 197 & 316 & 0.62 & 65 & 16.03 & 32 & 0.41 \\
\hline 223 & 1770.5 & 237 & 365 & 0.65 & 64 & 15.99 & 29 & 0.51 \\
\hline 229 & 1790.5 & 220 & 356 & 0.62 & 66 & 16.09 & 36 & 0.49 \\
\hline 233 & 1810.5 & 90 & 254 & 0.35 & 79 & 15.94 & 24 & 0.57 \\
\hline 238 & 1830.5 & 252 & 397 & 0.63 & 65 & 15.97 & 27 & 0.59 \\
\hline 250 & 1850.5 & 256 & 393 & 0.65 & 64 & 16.02 & 31 & 0.52 \\
\hline 255 & 1870.5 & 286 & 413 & 0.69 & 63 & 16.03 & 32 & 0.53 \\
\hline 265 & 1910.5 & 272 & 352 & 0.77 & 59 & 15.85 & 16 & 0.53 \\
\hline 269 & 1930.5 & 247 & 429 & 0.58 & 67 & 15.99 & 29 & 0.49 \\
\hline 274 & 1950.5 & 281 & 364 & 0.77 & 59 & 15.91 & 22 & 0.55 \\
\hline 282 & 1970.5 & 295 & 396 & 0.74 & 60 & 15.96 & 26 & 0.57 \\
\hline \multirow[t]{3}{*}{286} & 1990.5 & 280 & 413 & 0.68 & 63 & 15.99 & 29 & 0.51 \\
\hline & & & & Mean: & 69 & & 25 & 0.52 \\
\hline & & & & dard deviation: & 6.8 & & 7.8 & 0.05 \\
\hline
\end{tabular}

$\mathrm{cps}=$ counts per step. 